\title{
Elderly people receiving care through an aeromedical service
}

Keyla Cristiane do Nascimento?

Claudia Ferreira Fernandes²

Juliana Balbinot dos Reis Girondi3

Luciara Fabiane Sebold ${ }^{3}$

Karina Silveira de Almeida Hammerschmidt ${ }^{4}$

André Ricardo Moreira

\section{Abstract}

Objective: to characterize the care given to the elderly by an aeromedical service in the south of Brazil. Method: a descriptive, cross-sectional and quantitative study was performed. The data were collected from reports of care of the elderly between July 2014 and June 2016, and were analyzed using simple descriptive statistics with numerical measures and descriptive charts. Results: of the 1071 care visits performed, 214 (19.9\%) were related to occurrences involving the elderly, the majority of whom were male $(64.5 \%)$ and aged between 60-64 years (29\%). The types of care were classified into clinical, trauma or inter-hospital transfer. With respect to clinical care, cardiorespiratory arrest was the most prevalent incident $(35.9 \%)$, while in trauma care falls were the most frequent occurrence $(48.9 \%)$. The highest percentage of visits occurred on Sundays $(18.7 \%)$. In the majority of cases care resulted in referral to reference hospitals $(69.63 \%)$, followed by visits that evolved to death in the case of 47 elderly persons $(21.96 \%)$. Conclusion: the findings of the present study represent a relevant contribution to the planning and implementation of care for elderly persons in an emergency situation receiving treatment from an aeromedical service.
Keywords: Nursing. Elderly. Air Ambulances. Emergencies. Emergency Medical Services.

Epidemiology Descriptive.

Universidade Federal de Santa Catarina, Departamento de Enfermagem. Florianópolis, SC, Brasil.

2 Estratégia de Saúde da Família, Secretaria Municipal de Saúde. São José, SC, Brasil.

3 Universidade Federal de Santa Catarina, Departamento de Enfermagem, Programa de Pós-graduação Gestão do Cuidado de Enfermagem. Florianópolis, SC, Brasil.

4 Universidade Federal de Santa Catarina, Departamento de Enfermagem, Programa de Pós-graduação em Enfermagem. Florianópolis, SC, Brasil.

5 Serviço de Atendimento Móvel de Urgência, Grupo de Resposta Aérea de Urgência do Batalhão de Operações Aéreas. Florianópolis, SC, Brasil. 


\section{INTRODUCTION}

With the disorganized development of cities, urban mobility has become more complex, making it difficult to provide rapid health care by land, especially in more remote locations.

It is understood that the survival of a critical patient is directly related to the speed with which they are submitted to suitable definitive treatment ${ }^{1}$. Faced with such a reality, the need for prompt and adequate care in the prehospital phase is imperative. Factors such as time of day, traffic movement, the distribution of mobile service units and the location to which the patient will be referred directly influence prehospital care time.

Aeromedical services are important in this context, as patients in a serious condition require the rapid displacement of health professionals, reducing the risk of deterioration of their critical state of life. Aeromedical care is a complex activity aimed at finding, locating, rescuing and caring for patients who have suffered accidents, violence or medical problems in distant, remote or difficult to reach places which ambulances cannot easily access, or disaster situations such as earthquakes, floods, fires, air crashes and shipwrecks ${ }^{2}$.

With the increase of longevity in Brazil, there is a need to structure health services to provide specialized attention, especially regarding the rapidity of emergency and urgent care, as the physiological organic systems of elderly persons are frailer due to the changes caused by aging. The structural and functional alterations associated with multimorbidity predispose the elderly to accidents and explain the basic differences in health/illness outcomes ${ }^{4}$. The response of geriatric patients to injuries is less effective than among young adults and the results are more frequently fatal, even when severity is low ${ }^{5}$.

The aeromedical service should therefore be prepared to meet the needs of the elderly in order to maintain the quality of care and the positive results obtained by the interventions performed.
In Santa Catarina, the location of the present study, the Corpo de Bombeiros Militares de Santa Catarina (the Santa Catarina Fire and Emergency Service) (CBMSC) working in partnership with the Serviço de Atendimento Móvel de Urgência (the Mobile Emergency Response Service) (SAMU/ SC) created, in 2010, the Batalhão de Operações Aéreas (the Air Operations Battalion) (BOA) ${ }^{6}$. This service operates with a Squirrel model (HB 350 B) rotary-wing aircraft, known as Archangel 01 (Advanced Life Support Helicopter). This aircraft has the capacity to transport six people, namely two pilots, two to three crew members (operational flight crewmember, doctor and nurse) and one patient.

This is a relatively new service, with a need for further studies on the needs of those using the service, especially when serving the largest part of the population (the elderly), so that specific action plans can be created to meet the growing demand for care of this group.

The following research question is therefore asked: what is the sociodemographic profile and characteristics of the care provided to the elderly by the BOA Santa Catarina aeromedical service? The objective of the study was to characterize the profile of the elderly assisted by the aeromedical service of the Santa Catarina Batalhão de Operações Aéreas.

\section{METHOD}

A quantitative, descriptive, cross-sectional study of retrospective documentary type was carried out. The data were collected from records of digitized care reports, covering occurrences with the elderly in the period between July 2014 and June 2016, representing 214 call-out visits. The eligibility criteria were: people aged 60 years of age or older who were cared for and transported by the BOA advanced life support helicopter during the abovementioned period. Excluded were records in which no health care was provided by the SAMU/BOA service, such as fire-fighting records, transport of authorities or patrol flights. 
The variables gender, age group, month of occurrence, day of the week of occurrence, nature of occurrence and outcome of care were considered. To organize and record the data, a form was developed with the purpose of assisting in the retrospective analysis of the service reports completed by the $\mathrm{BOA}$ team. Descriptive statistics were used for analysis, with numerical measures and descriptive graphs, discussed through pertinent literature.

The study was approved by the Ethics Research Committee of the Universidade Federal de Santa Catarina (Santa Catarina Federal University), process $\mathrm{N}^{\circ}$ 1.691.870/2016, under Certificate of Ethical Evaluation (CAAE) number 57454116.9.0000.0121, complying with National Health Council (CNS) resolution n ${ }^{\circ} 466$ of 2012.

\section{RESULTS}

In the period between July 2014 and June 2016, 1,071 flights were performed by the Air Operations Battalion with the Archangel helicopter in the region of Greater Florianópolis. Of this total, 214 visits were related to occurrences with people over 60 years old, representing $19.90 \%$ of the total number of visits.

Regarding the gender variable, there were a total of 138 male patients $(64.48 \%)$ and 76 female patients $(35.52 \%)$ of the total number of care visits provided to the elderly.

The arithmetic mean age of the patients attended was 72.43 years and the age distribution is presented in table 1.

Table 1. Distribution by age group, clinical occurrences and occurrences of trauma of the elderly attended by the Archangel aircraft in the period between July 2014 and June 2016 (N.214). Florianópolis, Santa Catarina, Brazil, 2016.

\begin{tabular}{ll}
\hline Variables & $\mathrm{n}(\%)$ \\
\hline Call-outs by age-range (years) & $62(29 \%)$ \\
$60-64$ & $35(16 \%)$ \\
$65-69$ & $29(14 \%)$ \\
$70-74$ & $35(16 \%)$ \\
$75-79$ & $54(25 \%)$ \\
$>80$ & \\
Clinical occurrences & $52(35.9 \%)$ \\
Cardiopulmonary resuscitation & $36(24.8 \%)$ \\
Cardiology Emergency & $30(20.7 \%)$ \\
Stroke & $8(5.5 \%)$ \\
Respiratory Emergency & $6(4.1 \%)$ \\
Neurological Emergency & $13(9 \%)$ \\
Others & \\
\hline Trauma occurrences & $22(48.9 \%)$ \\
Falls & $16(35.6 \%)$ \\
Traffic-accidents & $3(6.7 \%)$ \\
Drowning & $2(4.4 \%)$ \\
Knife Injury & $1(2.2 \%)$ \\
Firearm Injury & $1(2.2 \%)$ \\
Others &
\end{tabular}


There was a predominance of clinical events, with 145 call-outs $(67.76 \%)$, followed by trauma, with 45 call-outs $(21.03 \%)$ and inter-hospital transfers, with 24 helicopter transported patients (11.21\%).

Table 1 shows the details of these statistics, according to the nature of the visits.

Among the Cardiological Emergencies treated, arrhythmias and acute myocardial infarcts were the most prevalent. In the clinical cases classified as Other, patients were treated for gastrointestinal bleeding, severe hypoglycemia, septic shock, acute chronic renal failure, psychiatric care and even elderly patients with cancer in palliative care.
Among the traffic accidents treated were car crashes ( 6 call-outs), tram accidents ( 6 call-outs) and accidents involving motorcyclists (4 call-outs).

Inter-hospital transfers were divided into clinical and traumatic. The total number of patients transferred by helicopter was 24, 22 of which were of a clinical nature and two of which were traumatic in nature.

In terms of the month of occurrence of the callouts, Figure (1) shows the quantitative (n) of call-outs according to the months of the year.

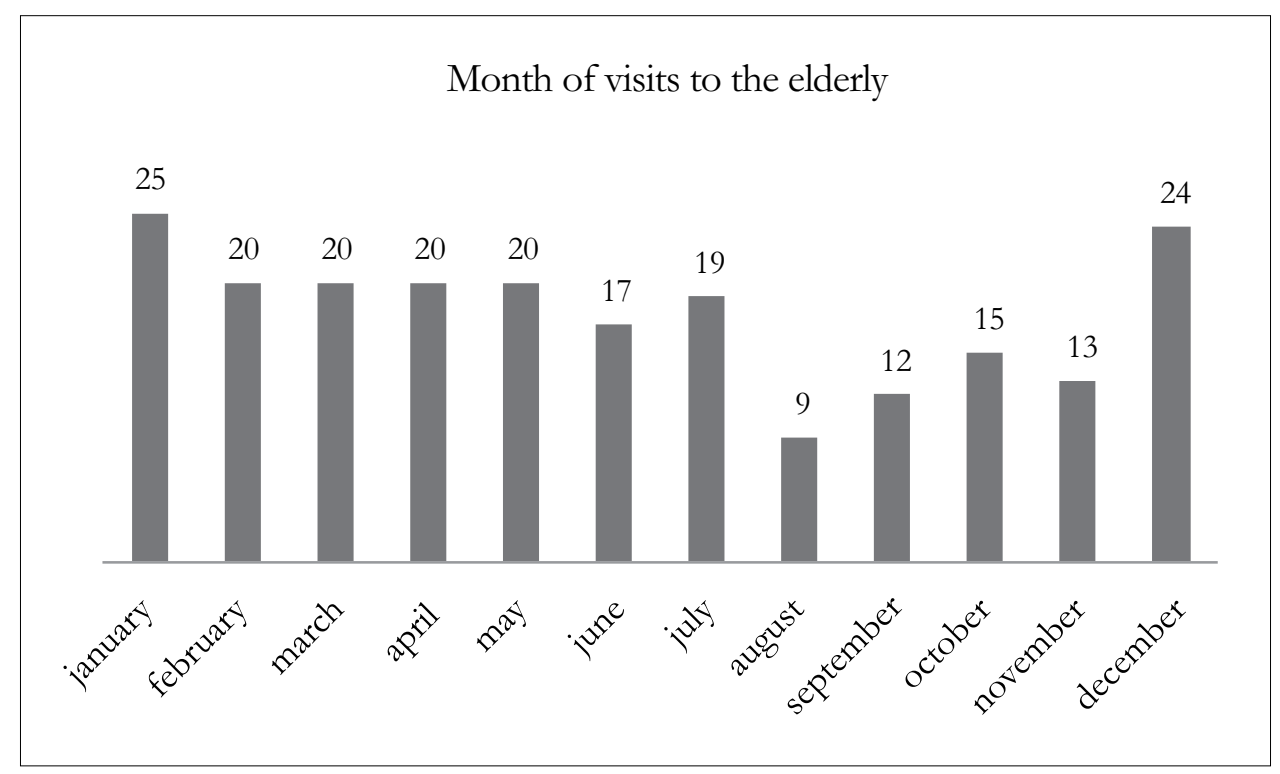

Figure 1. Monthly distribution of visits to the elderly made by the Archangel helicopter in the period between July 2014 and June 2016. Florianópolis, Santa Catarina, Brazil, 2016.

In relation to the occurrence rate per day of the week, the following variation was observed: on Sundays there were 40 call-outs (18.69\%); Mondays 26 call-outs $(12.15 \%)$, Tuesdays 27 call-outs $(12.62 \%)$, Wednesdays 35 call-outs (16.35\%), Thursdays 32 call-outs $(14.96 \%)$, Friday 30 call-outs $(14.02 \%)$ and Saturday 24 call-outs (11.21\%).

Regarding the outcome of the call-outs, the greatest number of elderly persons were referred to Public
Reference Hospitals (49, 69.63\%), while 47 elderly people died (21.96\%) in the call-out location after receiving care from the aeromedical service team, and were therefore not transported by the helicopter. Four elderly persons were referred to Emergency Care Units $(1.87 \%)$ and three elderly patients were directed to Basic Health Units (1.4\%). In 11 call-outs (5.14\%) there was no need for aeromedical transport for the continuation of treatment, or in other words the elderly were stabilized and released at the treatment location. 


\section{DISCUSSION}

People undergo many changes during aging, both in physical and physiological structure and in their emotional and social needs. As a result, they are more susceptible to illness and lesions and can lose their potential to combat a wide-range of diseases?

Researchers have reported that the majority of visits to elderly persons by a mobile prehospital care service were for females ${ }^{8,9}$. This contrasts with the findings of the present study, in which care for elderly males $(64.48 \%)$ prevailed.

The reality of the aeromedical service was characterized by the findings of a survey of SAMU in João Pessoa (Paraiba), which described the care provided to the elderly population and identified a greater demand for care related to clinical diseases. A study conducted in this city in 2011 analyzed 240 occurrences and identified 135 (56.25\%) visits of a clinical nature, $68(28.33 \%)$ trauma call-outs and 37 (15.41\%) other visits ${ }^{8}$.

In clinical care, the high index of cardiorespiratory arrest involving the elderly in a prehospital setting is notable. The conduct and protocol provided should be suitable for each type of patient and cardiorespiratory resuscitation should not be restricted among elderly patients due to concerns over its effectiveness ${ }^{10}$.

Also with regard to cardiac emergencies, some elderly patients may not experience pain symptoms during an episode of cardiac ischemia or acute myocardial infarction, especially those who are physiologically more tolerant, due to the collateral circulation around the cardiac tissue undergoing a low rate of blood flow ${ }^{10}$. This greater tolerance to symptoms can lead to a delay in seeking care among geriatric patients and a consequent worsening of health conditions.

In the treatment of strokes, prehospital care teams should avoid hasty judgments and not assume that symptoms of mental confusion and disorientation are natural to the aging process, but rather the outcome of an acute illness or exacerbated chronic disease process. The individual may also experience difficulty in limb movement or have suffered prior ischemia that hinders speech ${ }^{10}$. Such situations predispose the elderly to clinical instability. Health professionals need to be able to detect early signs and symptoms of cerebrovascular events and monitor and guide suitable interventions, considering the particular needs of this population.

The elderly often undergo multimorbidities, mainly chronic degenerative diseases. In 2007, $72 \%$ of deaths in Brazil were attributed to chronic noncommunicable diseases (CNCD), such as cardiovascular and respiratory diseases, diabetes, cancer and other conditions, including kidney diseases; $10 \%$ to infectious and parasitic diseases and $5 \%$ to maternal and child health disorders ${ }^{11}$. In this way, aging is associated with a higher prevalence of chronic diseases and disabilities, and is a phase of life in which the use of health services tends to increase ${ }^{12}$.

In this context health professionals have an important role in the promotion of educational actions for elderly persons with chronic disease. Health education in all contexts of health care can encourage positive behavior among the elderly, in order to control complications and increase adherence to treatment, with the aim of promoting a healthy life, even with the presence of chronic pathologies ${ }^{13}$.

In trauma cases, the care provided in relation to accidents due to falls, whether from their own height or other levels, is notable. One of the aspects most evident in the aging process is the physical disabilities and degree of dependence of the elderly. While functional disability is not inherent to the aging process ${ }^{14}$, as an individual ages, the chances of suffering injuries from accidents increase ${ }^{15}$. Studies have shown that such injuries are among the main causes of death in elderly people and that falls represent up to two-thirds of accidents with the elderly, becoming one of the main predictors of morbidity and mortality ${ }^{16,17}$.

Fall accidents can be caused by several factors, whether intrinsic and/or extrinsic ${ }^{18}$. Falls among the elderly constantly result in injuries and fractures, compromise activities of daily living, increase institutionalization rates, generate a decline in general health and increase fear of falling, which, in turn, increases the risk of a subsequent fall ${ }^{19}$.

Several studies have indicated the problem of falls among the elderly, as in addition to their high rate of occurrence, they can cause damages that 
affect the well-being of the individual and increase hospitalization and other health service costs, thus representing an important public health problem ${ }^{20}$. Preventive measures for accidents due to falls in the elderly should therefore be a constant theme in the implementation of public health policies focused on this population profile $8,10,16$.

The importance of traffic accidents among this population group should be discussed, given the complexity of the aging process and the seriousness of such incidents. In the USA, motor vehicle trauma is the leading cause of death due to trauma in the elderly population aged between 64 and 74 years of age $^{21}$; the elderly represent more than $20 \%$ of all pedestrian fatalities'.

International studies have reported that increasing age and the severity of lesion are predictive of complications and mortality. The increase in age reduces tolerance to the shock of collisions and a preexisting health problem can represent a risk of death that is up to $50 \%$ greater among the elderly ${ }^{21,22}$. These fatality rates were attributed to subtle memory and attention changes, along with decreased visual and auditory acuity, resulting in delayed reaction time ${ }^{22}$.

Anatomical and physiological changes associated with aging, chronic disease and medications can make elderly people more susceptible to trauma, complicate traumatic injuries and decrease the ability to compensate for hemorrhagic shock. Elderly patients have less physiological reserve and tolerate trauma poorly ${ }^{1}$.

In Singapore, a study with traumatized elderly people to identify the injury patterns, specific risk factors and needs of injured individuals, found that traffic accidents were the second greatest cause of trauma in this population ${ }^{23}$. These findings agreed with the results of the present study, where traffic accidents corresponded to the second most frequent cause of trauma in the elderly population, representing $35.56 \%$ of trauma occurrences.

In Brazil, the profile of events due to trauma in the elderly differs in some aspects from that of younger populations, with a greater vulnerability to being knocked down, as demonstrated by the high proportion of deaths $(48.2 \%)$ arising from this cause $^{24}$. The vulnerability of the elderly to traffic accidents is unquestionable and as a pedestrian this is accentuated by their greater exposure and restricted mobility at the time of the collision. With reduced mobility it is not always possible to cross wide streets in the time allotted by the traffic lights.

Another relevant aspect identified by the study is related to the transportation of elderly people between institutions. The aircraft is of great importance, not only in providing immediate care, but also in allowing quick, safe transfers. Transfers of critical patients between health institutions through helicopter transport with an advanced life support teams allows effective stabilization of the most serious cases $^{1,10}$. Helicopter transport can limit environmental exposure, shorten the duration of the care process and ensure faster access to specialist referral services ${ }^{1}$.

The results did not identify the predominance of occurrences on a particular day of the week, revealing that this group is subject to illness and trauma on any day, although there was a greater incidence of occurrences on Sundays. The greater number of attendances on that day may be related to the behavior adopted by the individuals, or the recreational activities performed at the weekend.

Regarding the distribution of visits in relation to the months of the year, seasonality was found to be important due to the number of occurrences in the months of December and January, influenced by the climatic differences of the region. The Greater Florianópolis region undergoes an expressive increase of tourists in the summer, reflecting in greater demand for health care.

Considering such seasonal demand, there is a need to allocate resources to anticipate seasonal changes to improve operational efficiency and maximize care for elderly patients, so that the supply of services corresponds to real demand in periods of higher numbers of call-outs ${ }^{1}$.

Regarding the final outcome of care, the participation of health services as an entry point for the elderly patients treated by the aeromedical service was notable. Excluding patients who were not transported to health services, $69.63 \%$ were transferred to a public hospital reference service, identifying the SUS-funded system as the main entry point for emergency situations. 
The aeromedical service is a type of health care that provides advanced support to the lives of severely ill elderly persons ${ }^{10}$ offering fast, efficient transportation to the location where definitive treatment can continue.

Greater approximation and understanding of the needs of the elderly can allow practitioners, especially nurses, to implement specific measures aimed at the elderly in emergency situations ${ }^{9}$, in order to promote greater quality in the initial care of such patients.

As they are inserted in all areas of pre-hospital emergency care, nursing teams should consider the possibility of implementing gerontological actions, given the particularity of the care required by the elderly, thus contributing to the reduction of sequelae and morbidities and mortalities arising from these occurrences.

As a limitation of the present study, in addition to having been performed in a single institution, there are issues inherent to cross-sectional retrospective studies, which do not allow the establishing of causal relationships. Also, the incipient nature of previous studies of aeromedical services made comparison of the results in the discussion difficult. A more detailed exploratory analysis about the procedures performed in the care of the critical elderly is recommended in later studies.

\section{REFERENCES}

1. McSwain EN, Frame S, Salomone PJ. PHTLS: PreHospital Trauma Life Support . 8th ed. Burlington: Jones \& Bartlett Learning; 2016.

2. Gentil RC. Transporte aéreo: o diferencial na assistência de enfermagem. In: Mallagutti W, Caetano KC. Transporte de pacientes: a segurança em situações críticas. São Paulo: Yendis; 2015. p. 47-65.

3. Dos Santos C, De Andrade L, Silva M, De Sousa M. Percurso do idoso em redes de atenção à saúde: um elo a ser construído. Physis [Internet]. 2016 [acesso em 03 fev. 2017];26(1):45-62. Disponível em: HYPERLINK "http://www.scielo.br/pdf/ physis/v26n1/0103-7331-physis-26-01-00045.pdf" http://www.scielo.br/pdf/physis/v26n1/0103-7331physis-26-01-00045.pdf

\section{CONCLUSION}

The aging process influences morbidity and mortality rates. Prehospital care for the elderly population presents peculiarities that differentiate such individuals from the care provided to young adults and which directly influence the care provided by the aeromedical service to the elderly patient.

This study identified that the elderly receiving care from the aeromedical service were mostly male, with a predominant age group of 60 to 64 years, who mainly suffered impairment of their clinical health conditions, especially through cardiorespiratory arrest.

It was verified that the main clinical events that affected the study population consisted of diseases of the cardiovascular system. With regard to trauma, falls required the most call-outs in the studied period.

The present study allowed an understanding of the characteristics of the care provided to the elderly by the aeromedical service, allowing the construction of standardized institutional protocols and training of multiprofessional staff aimed at the elderly person.

Finally, it is believed that this research has the potential to stimulate and contribute to reflections on the part of the teams that work in prehospital care, as well as evidencing and strengthening information about the aeromedical service.

4. Gonsaga RAT, Silva EM, Brugugnolli ID, Cabral JL, Thomé NO. Padrão e necessidades de atendimento pré-hospitalar a idosos. Rev Bras Geriatr Gerontol [Internet]. 2015 [acesso em 09 fev. 2017];18(1):19-28. Disponível em: http://www. scielo.br/scielo.php?script=sci_arttext\&pid=S180998232015000100019\&lng=en

5. Campbell JE, Alson RL. International Trauma Life Support for Emergency Care Providers (ITLS). 8th ed. Londres: Pearson; 2016.

6. Santa Catarina. Decreto n ${ }^{\circ}$ 2.966, de 02 de fevereiro de 2010. Cria e Ativa O Batalhão de Operações Aéreas do Corpo de Bombeiros Militar de Santa Catarina, e Estabelece Outras Providências. Florianópolis, 2010. Procuradoria Geral do Estado 
de Santa Catarina. Disponível em: HYPERLINK "http://www.pge.sc.gov.br/index.php?option=com_ wrapper\&Itemid=163" http://www.pge.sc.gov.br/ index.php?option $=$ com_wrapper\&Itemid $=163$

7. Da Silva DMA, Acevedo Samúdio M, Coutinho RN, Coutinho MLN, De Andrade LM. Perfil sociodemográfico e processo de hospitalização de idosos atendidos em um hospital de emergências. Rev RENE.[Internet]. 2015 [acesso em 01 mar. 2017];16(6):908-1005. Disponível em:HYPERLINK "http://www.redalyc.org/articulo. oa?id=3240432610207." http://www.redalyc.org/ articulo.oa?id=324043261020

8. Patrício A, Santos J, De Albuquerque K, Alves K, Duarte M, Pérez V. Mobile pre hospital attendance: identification aggravations for the elderly person. Rev Pesqui Cuid Fundam [Internet]. 2016 [acesso em 22 fev. 2017];8(2):4223-30. Disponível em: http://www. seer.unirio.br/index.php/cuidadofundamental/article/ view/4217/pdf_1861

9. Gonsaga RAT, Silva EM, Brugugnolli ID, Cabral JL, Thomé Neto O. Padrão e necessidades de atendimento pré-hospitalar a idosos. Rev Bras Geriatr Gerontol [Internet]. 2015 [acesso em 09 jan. 2017];18(1):1928. Disponível em: HYPERLINK "http://dx.doi. org/10.1590/1809-9823.2015.13171"http://www. scielo.br/scielo.php?script=sci_arttext\&pid=S180998232015000100019\&lng=en. http://dx.doi. org/10.1590/1809-9823.2015.13171

10. Snyder DR; American Association of Emergency Medical Technicians. Geriatric Education for Emergency Medical Services (GEMS). 2nd ed. Burlington: Jones \& Bartlett Learning; 2016.

11. Schmidt MI, Duncan BB, Silva GA, Menezes AM, Monteiro CA, Barreto SM, et al. Chronic noncommunicable diseases in Brazil: burden and current challenges. Lancet [Internet]. 2011[acesso em 23 jan. 2017];377(9781):1949-61. Disponível em: http:// www.thelancet.com/pdfs/journals/lancet/PIIS01406736(11)60135-9.pdf

12. Focchesatto A, Rockett FC, Perry IDS. Risk and protective factors for the development of chronic diseases in a rural elderly population in Rio Grande do Sul. Rev Bras Geriatr Gerontol [Internet]. 2015 [acesso em 30 jan. 2017];18(4):779-95. Disponível em: http://www.scielo.br/scielo.php?script $=$ sci_ arttext\&pid=S1809-98232015000400779\&lng=en

13. Valcarenghi RV, Lourenço LFL, Siewert JS, Alvarez AM. Nursing scientific production on health promotion, chronic condition, and aging. Rev Bras Enferm [Internet]. 2015 [acesso em 30 jan. 2017];68(4):705-12. Disponível em: http://www. scielo.br/scielo.php?script $=$ sci_arttext\&pid $=$ S0034$71672015000400705 \& \operatorname{lng}=$ en
14. Amorim JSC, Salla S, Trelha CS. Fatores associados à capacidade para o trabalho em idosos: revisão sistemática. Rev Bras Epidemiol [Internet]. 2014 [acesso em 09 jan. 2017];17(4):830-41. Disponível em: HYPERLINK "http://www.scielo.br/scielo. php?script=sci_arttext\&pid=S1415-" http://www. scielo.br/scielo.php?script $=$ sci_arttext\&pid=S1415790X2014000400830\&lng=en

15. Campolina AG, Adami F, Santos JLF, Lebrão ML. Expansion of morbidity: trends in healthy life expectancy of the elderly population. Rev Assoc Med Bras [Internet]. 2014 [acesso em 30 jan. 2017];60(5):434-41. Disponível em: HYPERLINK "http://www.scielo.br/ scielo.php?script $=$ sci_arttext\&pid=S010442302014000500434\&lng=en\%20" http://www. scielo.br/scielo.php?script $=$ sci_arttext\&pid $=$ S010442302014000500434\&lng=en

16. Del Duca GF, Antes DL, Hallal PC. Quedas e fraturas entre residentes de instituições de longa permanência para idosos. Rev Bras Epidemiol [Internet]. 2013 [acesso em 08 jan. 2017];16(1):6876. Disponível em: HYPERLINK "http:// dx.doi.org/10.1590/S1415-790X2013000100007" http://www.scielo.br/scielo.php?script $=$ sci_ arttext\&pid=S1415-790X2013000100068\&lng=en. http://dx.doi.org/10.1590/S1415790X2013000100007

17. Jorge MHPM, Cascão AM, Laurenti R. Em busca de melhores informações sobre a causa básica do óbito por meio de linkage: um recorte sobre as causas externas em idosos - Estado do Rio de Janeiro, Brasil, 2006. Epidemiol Serv Saúde [Internet]. 2012 [acesso em 08 jan. 2017];21(3):407-18. Disponível em: HYPERLINK "http://scielo.iec.pa.gov. br/scielo.php?script=sci_arttext\&pid=S167949742012000300006\&lng=pt" http://scielo.iec. pa.gov.br/scielo.php?script $=$ sci_arttext\&pid $=$ S167949742012000300006\&lng=pt

18. Mallmann DG, Hammerschmidt KSA, Santos SSC. Instrumento de avaliação de quedas para idosos (IAQI): enfermeiro analisando vulnerabilidade e fragilidade. Rev Bras Geriatr Gerontol [Internet]. 2012 [acesso em 30 jan. 2017];15(3):517-27. Disponível em: http://www.scielo.br/scielo.php?script $=$ sci_ arttext\&pid=S1809-98232012000300012\&lng=en

19. Carneiro JA, Ramos GCF, Barbosa ATF, Vieira EDS, Silva JSR, Caldeira AP. Falls among the noninstitutionalized elderly in northern Minas Gerais, Brazil: prevalence and associated factors. Rev Bras Geriatr Gerontol [Internet]. 2016 [acesso em 30 jan. 2017];19(4):613-25. Disponível em: http://www. scielo.br/scielo.php?script=sci_arttext\&pid=S1809$98232016000400613 \& \operatorname{lng}=$ en 
20. Sandoval RA, Sá ACAM, Menezes RL, Nakatani AY, Bachion AM. Ocorrência de quedas em idosos não institucionalizados: revisão sistemática da literatura. Rev Bras Geriatr Gerontol [Internet]. 2013 [acesso em 06 fev. 2017];6(4):855-63. Disponível em: http://www. scielo.br/scielo.php?script=sci_arttext\&pid=S180998232013000400855\&lng=en

21. Centers for Disease Control and Prevention [Internet]. Atlanta: CDC; 2013. Older adult drivers: get the facts; 2013 [acesso em 14 dez. 2016];[2 pág.]. Disponível em: http://www.cdc.gov/motorvehiclesafety/older_adult_ drivers_factsheet.html

22. Kent R, Trowbridge M, Lopez-Valdes FJ, Ordoyo $\mathrm{RH}$, Segui-Gomez M. How many people are injured and killed as a result of aging?: Frailty, fragility, and the elderly risk-exposure tradeoff assessed via a risk saturation model. Ann Adv Automot Med [Internet]. 2009 [acesso em 30 jan. 2017];53:41-50. Disponível em: HYPERLINK "http://www.ncbi.nlm.nih.gov/ pmc/articles/PMC3256801/" http://www.ncbi.nlm. nih.gov/pmc/articles/PMC3256801/

23. Yeo YYC, Lee SK, Lim CY, Quek LS, Ooi SBS. A review of elderly injuries seen in a Singapore emergency department. Singap Med J [Internet]. 2009 [acesso em 06 fev. 2017];50(3):278-83. Disponível em: HYPERLINK "http://smj.sma.org.sg/5003/5003a6. pdf" http://smj.sma.org.sg/5003/5003a6.pdf

24. Broska Junior CA, Folchini ABD, Ruediger RR. Estudo comparativo entre o trauma em idosos e não idosos atendidos em um Hospital Universitário de Curitiba. Rev Col Bras Cir [Internet]. 2013 [01 fev. 2017];40(4):281-6. Disponível emHYPERLINK "C: Downloads $\backslash$ : http: $\backslash w w w . s c i e l o . b r \backslash p d f \backslash r c b c \backslash v 40 n 4 \backslash$ v40n4a05.pdf": http://www.scielo.br/pdf/rcbc/ v40n4/v40n4a05.pdf 